Bu makaleye atıfta bulunmak için/To cite this article:

DOĞAN, Z. N. AKBAȘ, E. (2021). An Exploratory Study of Epistemic Stance in Results and Discussion Sections of Medical Research Articles. Atatürk Üniversitesi Sosyal Bilimler Enstitüsü Dergisi, 25 (3), 1132-1150.

\title{
An Exploratory Study of Epistemic Stance in Results and Discussion Sections of Medical Research Articles
}

\author{
Zeynep Nur DOĞAN (*) \\ Erdem $A K B A S^{(* *)}$
}

\begin{abstract}
This study is a corpus-based investigation of how epistemic stance is signaled in medical discourse. In particular, we compiled a discipline-specific corpus of research articles from different fields of medicine ranging from anatomy to endocrinology to explore how particular resources are employed by authors to index their level of (un)certainty towards their propositions. The corpus of the study contained only the results and discussion sections of 100 published medical research articles, totaling approximately 215,000 words. The results of the corpus analyses showed that there was very frequent use of modal auxiliaries by the writers in the field of medicine to express their extra-propositional modality. It was also found that medical researchers did not employ a greater number of boosters to amplify their commitment to the propositions conveyed to the readers. However, the rhetorical uses of boosters were shown to be strategic to portray their higher level of confidence for the sake of credibility and interaction. The findings and implications are discussed with a particular focus on the teaching of writing as a part of English for academic purposes.
\end{abstract}

Keywords: Epistemic stance, metadiscourse, medical academic writing, hedges and boosters, corpus linguistics

\section{Tıp Alanındaki Araştırma Makalelerin Sonuç ve Tartışma Bölümlerindeki Bilgisellik İfadeleri Üzerine Keşifsel Bir Çalışma}

Öz: Bu çalışma, bilgisellik ifadelerinin tıbbi söylemde nasıl işaret edildiğinin derlem-tabanlı bir incelemesidir. Özellikle, yazarlar tarafindan önermelerine karşı kesinlik (belirsizlik) düzeylerini belirtmek amacıyla belirli kaynakların nasıl kullanıldı̆̆ını keşfetmek için tıbbın anatomiden endokrinolojiye kadar değişen farklı alanlarından disipline özgü bir araştırma makaleleri derlemi kullanılmıştır. Araştırmamızın derlemi toplamda yaklaşık 215.000 kelimeden oluşan 100 yayınlanmış tıbbi araştırma makalesinin sadece sonuçlar ve tartışma bölümlerini içermektedir. Derlem analizlerimizin sonuçlar tıp alanındaki yazarlar tarafindan ek-önerme kipliğini ifade etmek için çok sık kip belirteçleri kullanımı olduğunu gösterdi. Ayrıca tıp araştırmacılarının, okuyuculara aktarılan önermelere dair değerlendirmelerini kuvvetlendirmek

\footnotetext{
*) Postgraduate Student, Erciyes University Graduate School of Educational Sciences (e-mail: nurzdogan95@gmail.com) (iD ORCID ID.https://orcid.org/0000-0003-4886-0440

**) Assistant Prof. Dr., Erciyes University Faculty of Education ELT Department (e-mail: erdemakbas@erciyes.edu.tr) (DD ORCID ID.https://orcid.org/0000-0003-2204-3119

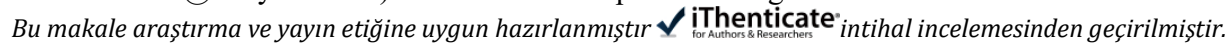


için çok fazla sayıda güçlendirici kullanmadıkları sonucuna ulaşılmıştır. Buna rağmen, güçlendiricilerin retorik kullanımlarının etkileșim ve inanılırlık uğruna daha yüksek güven düzeylerini sergilemek için stratejik olduğu tartışılmaktadır. Bulgular ve çıkarımlar, akademik amaçlarla İngilizcenin bir parçası olarak yazma öğretimi üzerine özel bir odak ile tartışılmıştır.

Anahtar Kelimeler: Bilgisellik ifadeleri, üstsöylem, tıbbi akademik yazma, kaçınma ve vurgulayıcılar, derlem dilbilim

Makale Geliş Tarihi: 11.06.2021

Makale Kabul Tarihi: 20.09.2021

DOI: 10.53487/ataunisosbil.951126

\section{Introduction}

Metadiscourse, a term used in discourse analysis, provides us with the necessary information about the way language is used by the writers or speakers of different genres, especially in terms of the choices made specifically for the transmission of knowledge. Hyland (2005a:3) stated that metadiscourse embraces the idea of communication as an exchange of attitudes, personalities and presumptions of the communicators rather than a mere information exchange. Writers or speakers employ different preferences while expressing their ideas, involving their stance and the way in which they engage with the readers. While interacting with readers/listeners, specific markers or signals are used to deliver particular functions of language. By using such markers, writers display their choice about the effect which they intended to have on the readers or listeners. Gray and Biber (2014) stated that in some written academic texts (such as research articles and theses), the writers' level of commitment, emotions and evaluation towards their propositions have been an area of interest, and the linguistic devices of a variety of terms signaling hedging (Brown \& Levinson, 1987: 37; Varttala, 2001: 1), commitmentdetachment (Akbaş, 2014: 2; Akbaş \& Hardman, 2018: 832; Vassileva, 2001: 83) and (inter)subjectivity (White, 2003: 260) have been examined and compared across different groups. To explore such linguistic mechanisms, Hunston and Thompson (2000: 5) proposed the term 'evaluation' and Biber and Finegan (1988: 1, 1989: 94) suggested 'stance'. Both studies, however, relied on two functions; 1) the personal attitude and 2) the epistemic status of a proposition signaled by the language user.

Considering that stance becomes purposeful only when the parties in a particular discourse interact with each other, it can be acknowledged as a bilateral constituent of communicated language (Çiftçi \& Akbaş, 2021: 488). Language teaching should emphasize the significance of indicating stance in writing and provide writers, especially novice ones, in the field with the linguistic devices which are required for this to happen. Some genres might involve the interaction between the communicators on different levels for different purposes. For writers in an academic community, especially in the sciences such as medicine, the style in which they embody their findings and present them has a crucial role in terms of the credibility of the information. In addition, researchers' stances in expressing their deductions and beliefs are significant points since the area of work requires it. Thus, when teaching academic writing, specific linguistic 
Exploratory Study of Epistemic Stance in Results and Discussion Sections of Medical Research Articles

devices with their communicative functions should be taught to support the content of the writing in terms of increasing the level of persuasion or conveying uncertainty.

The aim of this study is to investigate the epistemic stance in medical research articles and explore how the writers of these articles convey their degree of certainty towards their propositions to the readers through the use of modal auxiliaries, hedges and boosters in the results and discussion sections of their articles. The primary aim of the study is to inform academic writers in the medical profession about how epistemic stance is expressed in their particular field, the frequency of specific epistemic markers preferred in written academic medical discourse and the implications for their community.

\section{Literature Review}

\section{A. Defining epistemic stance}

In an instruction book for a flat-pack dining table purchased from IKEA, you are told what you have to do to set the table up through a series of steps, either by pictures or written instructions (or a mixture of both) which are definite and direct.
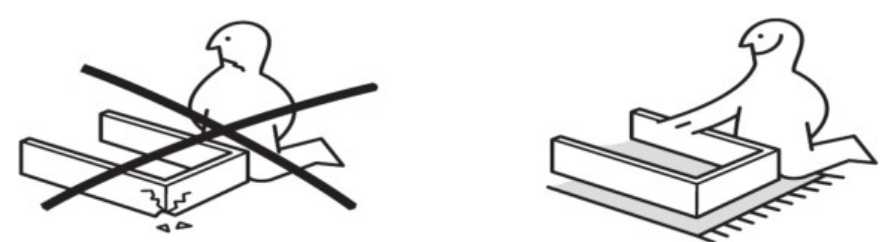

Figure 1. IKEA Melltorp Dining Table 68X29 Assembly Instruction

The producer of the illustration shown in Figure 1 interacts with the reader through a cartoon character and its facial expression for particular actions in setting the table up. Through the examples of some actions, users can understand the stance of the illustrator on the information provided and persuasion can be achieved by illustrating the desired/undesired outcome. Following the steps depicted in the illustrations, readers can be convinced of the truthfulness of this instruction book. However, the realization of credibility cannot be achieved in the same way for scientific propositions presented in a text in which readers might not have an opportunity to experience a trial-and-error process or are not provided with solid evidence of the information in question.

Hyland and Jiang (2016: 2) suggested that "the ways that writers and speakers express their opinions is an important feature of all interaction, and researchers have long been concerned with describing how stance is linguistically marked". This notion of interaction on the part of writers has been explained with different labels, such as 'attitude' (Halliday, 2004: vii), but the most widely known concepts about stance might be 'evidentiality' (Chafe \& Nichols, 1986: 4) and 'affect' (Ochs \& Schieffelin, 1989: 1). The latter involves indicating personal attitudes and feelings towards the proposition whereas the former, as Chafe and Nichols (1986) stated, refers to the source of 
knowledge, the modes of it and the continuum of the most reliable to the least reliable. The modes of knowledge are belief, induction, hearsay and deduction, each of which has a different source, such as hypotheses being the source of deduction or evidence for induction. The degree of reliability varies based on some linguistic choices and this is called the 'epistemic stance' of the writer. Epistemic stance indicates the writer's assessment of a proposition and the credibility of the knowledge. It can be realized through various linguistic devices such as adverbs:

(1) I will probably be in Portland next week.

(2) We go there maybe once or twice a month.

(3) We have approximately three hundred copies left.

In the example sentences above, the adverbs 'probably', 'maybe' and 'approximately' are used as indicators of the epistemic stance of the utterance owners. In sentence (1), the communicator talks about his/her future plans but is not entirely sure of the proposition so expresses it with the use of the adverb 'probably'. The listener or reader can understand from this that there is no certainty in the proposition to indicate that the speaker will definitely be in Portland next week or has even purchased a ticket to go there. Sentence (2) is also a weak statement in terms of certainty. The communicator does not know for sure how often they go to that specific place ('there') in a month. The same goes for example (3), in which the copies left do not have a precise number but even so three hundred is a close guess. Adverbs of this type which qualify a weaker epistemic status about the evaluation of the proposition are called hedges. Modal auxiliary verbs, which serve extrinsic modality (Vázquez, 2010), can also be used as hedges and they point out "the assessments of likelihood: possibility, necessity or prediction" (Biber et al., 1999: 485). This logical modality involves a human judgement of what is or is not likely to happen.

(4) Vanessa may not like the idea of you wearing her dress.

(5) It could help with your fever.

Example (4) with the negative form of 'may' as the modal auxiliary signals the epistemic possibility about the reaction of Vanessa when her dress is worn by someone else. It is likely that she would not like it, yet there is still uncertainty on the part of the communicator. The use of 'may' here therefore indicates the doubt. Example (5) has the modal 'could' as the signal of epistemic stance which emphasizes the faint possibility of 'it' decreasing the fever. The implicit message in this sentence could be that there are some ways which might cure the fever problem and 'it' could be one of them with a relatively higher degree of certainty than others.

The other linguistic devices which imply a writer's commitment to a claim are boosters. They support writers in declaring a strong claim and assertion about their proposition and allow direct engagement with readers (Akbaş \& Hardman, 2018; Hyland, 1998; Vassileva, 2001). Unlike hedges, boosters are used to display certainty and intense allegation. Some examples of boosters are given below. 
Exploratory Study of Epistemic Stance in Results and Discussion Sections of Medical Research Articles

(6) Well, at certain wards this is definitely the case. (10_1371_journal_pone_0084905)

(7) The result of the exam shows that she has improved in Math.

Example (6) has the adverb 'definitely' as a booster and talks about a specific situation and states that it takes place in some wards of probably a hospital since the sentence is taken from a medical research article. The adverb 'definitely' displays a strong certainty about whatever the case is which happens in some wards and the readers can understand that the writer is sure that the case is available in some wards or has been a witness of it. The verb 'shows' in example (7) is dependent to the subject noun 'result' and suggests that the writer is sure about the proposition because of the evidence supporting the claim of the improvement in Math. The implicit message in this sentence could be that 'I do not claim it; the exam result is the source and it is solid'.

There have been several studies of the use of hedges and boosters to communicate the degree of truth and assertion about a proposition or a statement. Some of these studies will be discussed in the next section.

\section{B. Previous studies on epistemic stance}

Previous studies of epistemic stance have been spread across a wide range of disciplines and have involved the analysis of particular markers using different frameworks and approaches. Poole et al. (2019) explored the epistemic stance within a diachronic corpus of biochemical research and adapted the frameworks used by Hyland (2005a; 2005b) and Biber (2006). The corpus was composed of research articles written between 1971 and 2017 and divided into five time periods. The results showed that as modal auxiliaries, the frequencies of 'can' and 'will', which express the highest commitment and certainty, exhibited an increase over time. These two core modals had higher fluctuations than the modals 'would', 'should' and 'might'. Even though their frequency showed a decrease, this implied that the necessity of hedging and being cautious about putting forward claims is less urgent since the shared body of knowledge in the discourse community might be consolidated. As hedges, 'often', 'suppose', 'around', 'assume', 'typical', 'estimated', 'frequently' and 'probable' were the epistemic adverbials which showed an increase over time, whereas 'demonstrate', 'clear', 'find', 'show' and 'know' were the boosters with the highest strong and clear increase trend. The study of Poole et al. (2019) overall indicated a decrease in the use of hedges in its specific domain of study (chemotaxis/biochemical research) and implicitly displayed the maturation of this field in terms of shared knowledge.

Other studies used different approaches in their analysis. Yang et al. (2015) looked at medical research articles, as this current study does, and exclusively targeted epistemic modality to analyse the corpus data. Their data were composed of 25 English-medium medical research articles written by native speakers and they investigated them from a systematic functional perspective. Their findings were given under sub-headings which displayed the function of the epistemic modality found: "Subjectivity and objectivity, 
certainty-uncertainty, politeness" were among them. The results showed that "writers tend to use low or median value epistemic modal expressions and epistemic modal expressions with implicitly subjective/objective or explicitly objective orientations" (Yang et al., 2015: 9) and this indicated that native-speaker medical research writers exhibited a tentative and objective manner when making their claims and restrained themselves from being subjective.

Hyland and Jiang's (2016) study focused on the concept of stance and investigated evidentiality, affect and presence in academic writing using a diachronic approach. Three hundred and sixty research articles from four disciplines (Sociology, Applied Linguistics, Biology and Engineering) formed their corpus and the focus was on three periods over the past fifty years from 1965, 1985 and 2015. Their findings in terms of evidentiality, which refers to the epistemic aspect of stance, showed variations across both disciplines and time. The soft-knowledge disciplines of Sociology and Applied Linguistics had a decrease in terms of the frequency of the hedges and boosters used. 'May' and 'would' were the most frequently used hedges in both of these disciplines. As a booster, 'must' was the predominant device used to express certainty in both disciplines in 1965 and 1985; by 2015, however, it was not in the top twenty most frequently used boosters. In the hard sciences, Biology and Engineering, the results showed the opposite. The use of hedges in these disciplines displayed an increase and the most frequently used epistemic modal was 'may' which had a higher degree of certainty than 'might'. As for the boosters, these two disciplines showed dissimilar results, because Biology showed a fall in the use of boosters whereas Engineering showed a steady rise. All in all, the summary of the results of that study indicated a decrease in the marking of evidentiality in soft disciplines over the last 50 years. Although there was an increase in the use of hedges, the tendency was on softening personal judgments and hedge quantities.

Examination of these studies shows the distinctness of the use of epistemic stance across disciplines. Two of the three studies discussed above suggested the dominance of hedging and the study which shares the same discipline with this current study (Yang et al., 2015) reported that writers preferred a more tentative stance in their writings. In line with the findings of these studies, the current study reported in this paper was designed to investigate the use of epistemic stance in the results and discussions sections of medical research articles and to analyse how the writers in this particular field of hard science convey their commitment and certainty.

\section{Corpus and Method}

Because this study targets the use of epistemic stance in medicine and health sciences, the corpus was composed of the results and discussion sections of 100 medical research articles which were obtained by using a discipline-specific corpus creation tool AntCorGen (Anthony, 2019). The process of acquiring the data using this tool was through the random sampling function of the tool. No specific medical or health sciences sub-fields were chosen in advance so the articles were from different medical fields ranging from anatomy to endocrinology. The resulting corpus of results and discussion sections had approximately 215,000 words in total. 
Exploratory Study of Epistemic Stance in Results and Discussion Sections of Medical Research Articles

The reason why the results and discussion sections of research articles were selected was solely because these are the two sections in which the writer is expected to evaluate findings and derive claims or information based on them. Similarly, the sole purpose of this current study was to analyse the use of epistemic stance when making those assertions and evaluations and how the writers interacted with readers in terms of expressing their degree of commitment or detachment, credibility, and how the writers sought to persuade the reader to take their argument into consideration. Akbaş and Hardman (2018: 838-839) stated that there have been various studies which have centred around the rhetorical organization of scientific research articles focusing on one particular section, but even so, discussion sections have received relatively less attention.

As already explained, the analysis of our corpus was conducted using the concordance software AntConc (Anthony, 2020). This current study followed the interactional metadiscourse framework of Hyland (2005a) and focused on the hedging and boosting resources on the basis of Hyland's (2005a) list. Since the modal auxiliaries which have an epistemic function were found to have the highest frequency of usage, they were analysed separately from the hedges or boosters and were examined and evaluated under a different heading, as was done by Poole et al. (2019). In total, eight core modals, 56 hedging devices and 42 boosters were included in the analysis. Because of the size of the corpus, the occurrence frequencies were normalized to per 10,000 words in order to provide comparability with the different data sizes.

Since modal verbs have both deontic (basic meaning) and epistemic functions, this difference of perception in their expression was present in the corpus. During the contextual and manual analyses, we therefore considered the epistemic and deontic functions of the same expressions so as not to include deontic functions, as illustrated in (8) below.

(8) Theoretically, chemotherapy can control the small metastatic sites around the main primary tumor, reduce the tumor dissemination or increase the tumor resection rate by shrinking the tumor, or improve the effect of radiotherapy and improve the long-term curative effect. (10_1371_journal_pone_0164840)

Example (8) from our corpus has the deontic modal 'can' which expresses a shared knowledge of the field to which this article refers. Here the modal verb signals the capability of chemotherapy which is a drug treatment to remove fastgrowing cells in the body. The word 'theoretically' at the beginning of the sentence emphasizes the strength of the statement and informs the reader about the operational feature of the treatment. This can be given as an example of the deontic use of modal verbs. Instances which displayed deontic modality were therefore excluded from the data analyses. 
Because the corpus was compiled from a field which can be accepted 'hard sciences', the outcome of the analysis was expected to be in line with the findings of Hyland and Jiang (2016) and Yang et al. (2015).

\section{Results and Discussion}

\section{A. Modal Auxiliaries}

Modal auxiliaries ('can', 'may', 'might', 'would', 'will', 'should', 'could', 'must') were the dominant linguistic devices with a frequency of 1220 instances, although not all of them reflected an epistemic stance, as stated in Section 3. Excluding 133 cases of deontic modal meanings, 1,087 cases of modal verbs contributing to the presentation of epistemic stance across the corpus were identified (see Table 1).

The most frequently employed modal verb was found to be 'may', followed by 'could' and 'can' respectively. The high occurrence of 'may' shows the writers' uncertainty towards their propositions and weakening their claim exhibits their preference to make space for different interpretations in the medical corpus. The examples below include the primary examples of 'may' from the corpus:

(9) Date of cancer diagnosis and the unavailability of data on confounding factors may affect the results. (10_1371_journal_pone_0182877)

(10) HPV subtype may also have a role, yet the impact of viral subtype currently remains unknown. (10_1371_journal_pone_0181108)

(11) Our data suggest that there may be a difference between the general characteristics of ESCC patients from China and western countries. (10_1371_journal_pone_0069259)

Table 1. Frequencies of the eight core epistemic modals

\begin{tabular}{lcc}
\hline Modal Verbs & Raw frequency & per 10,000 words \\
\hline may & 439 & 20.39 \\
could & 170 & 7.90 \\
can & 159 & 7.38 \\
might & 144 & 6.69 \\
would & 109 & 5.06 \\
will & 55 & 2.55 \\
should & 11 & 0.51 \\
must & 0 & 0.00 \\
\hline Total & $\mathbf{1 0 8 7}$ & $\mathbf{5 0 . 4 8}$ \\
\hline
\end{tabular}

Example (9) is the evaluation of the mentioned 'results' and the writer implies that there are some factors which affect the results and that the date of the cancer diagnosis and the unavailability of data are two of the possible ones. 'May' hints at a higher possibility than 'might' or 'could', which indicates that the writer is likely to think that these factors would have more chances than other factors. Even so, in order to respect the ideas of colleagues, the writer might have been trying to be cautious and therefore 
Exploratory Study of Epistemic Stance in Results and Discussion Sections of Medical Research Articles

hedged the proposition. Similarly, example (10) displays uncertainty on the part of writer towards the assertion and supports this doubt with the subsequent clause which states the uncharted impact of the subtype in question. Example (11) has two hedging devices which contribute to the mitigation of the author(s) towards the knowledge claim presented. The author(s) made a comparison between the patients from China and from those from western countries and the resource for this weak claim could be the data. However, the verb 'suggest' functioning as a hedging device displays detachment and 'may' implies a lack of confidence in the credibility of the data.

It was also found that clusters of 'may' were mostly comprised of 'may have past participle' and indicated assumptions about the treatment types, findings, viruses or diseases. The primary reason for this cluster being predominant in the overall uses of 'may' with 179 instances could be the authors' intention to contribute the past meaning of the given possibility. Example (12) below shows the possibility of micro-metastases already spreading to other organs and introduces a field-specific eventuality:

(12) Micro-metastases may have already spread to other distant organs or tissues; it remains unclear how effectively induction chemotherapy can target these undetectable lesions. (10_1371_journal_pone_0160758)

In addition, the field-specific word 'patient' was the most frequent word in the corpus and the modal 'may' was the epistemic device which primarily accompanied it. This was not surprising since this modal was clearly preferred by the writers over other modal verbs, as shown in Table 1.

The modal verb 'can' was also present in the corpus with deontic ability/capability functions, so these instances were excluded, as explained above. The rest of the epistemic stances established by the modal verb 'can' $(n=159)$ exhibited a high possibility. Similarly, the instances of 'could' included the past ability/inability and the epistemic usage implied low possibility. One of the two sample sentences below reflects the patient's talk in the articles and presents the deontic ability usage of modal 'can' and the other displays the past inability function of 'could':

(13) They wonder: "What will happen to me? Is there really nothing they can do for me?” (Male GP, 60 years, FG 2) (10_1371_journal_pone_0084905)

(14) Unfortunately, only 81 (57\%) patients could be analysed for LRC, due to the lack of local-regional status data. (10_1371_journal_pone_0151899)

The epistemic instances of 'can' and 'could' in examples (13) and (14) show different degrees of possibility. 'Can' indicates higher certainty than 'could' and instances of 'could' in the data were more frequent than those of 'can'.

(15) RT can be an effective treatment option for aggressive fibromatosis and can be considered for both resected tumors with local recurrences and unresectable tumors as the sole treatment. (10_1371_journal_pone_0198134) 
(16) However, because persistently increased D-dimer levels could be a marker of a more thrombogenic condition or larger tumor burden, it is conceptually reasonable that we postulated ... (10_1371_journal_pone_0172793)

Epistemic meaning established by the use of 'can' and 'could' primarily reflected their use in examples (15) and (16). For example, the two instances of 'can' in example (15) suggest that one possible reasonable option for fibromatosis (a kind of tumour) is most likely RT and the writer has a positive stance towards the credibility and reliability of this treatment but nevertheless weakens the claim to hint, perhaps, at as yet undetected side effects or complications, or it is maybe because the study of the tumor and this treatment is not sufficient to make strong assertions. Similarly, in example (16), by using 'could', the writer successfully hedges the claim and links the low possibility of the first proposition to the subsequent deduction.

The fourth most frequent modal was 'might' and it exhibited similar uses to those of 'may' but displayed slightly lower possibility than 'may' did.

(17) In typical lesions, this procedure might also have been avoided because of the difficulty inherent for the age. (10_1371_journal_pone_0225479)

Example (17) above presents the most typical function of 'might' in the data. Similar to 'may', 'might have' phrases were common in the obtained corpus and in this sentence it emphasizes the possibility of the avoidance of 'this procedure' so far. However, the certainty degree is lower and the implicit message here is that there is such an option but not sufficient evidence to support the claim. The writer might have been drawing on previous experience, the advice of colleagues or other studies but it can be inferred that the writer was not certain about the effectiveness or the lack of harm from abandonment of the procedure.

The epistemic modal verbs 'would' and 'will' did not have as many occurrences as the other modal verbs. This preference might have resulted from the higher precision which they imply, especially 'will', which functions as a booster. The results showed that with 5.06 instances per 10,000 words, the modal verb 'would' occurred more than 'will' (2.55 per 10,000 words) did. Many instances of 'will' were deontic and had the function of planning the future. Epistemic 'will' implied a high level of certainty for the expected outcome whereas 'would' weakened the proposition and displayed a level of detachment from the proposition. Examples (18) and (19) below are basic examples of these two epistemic markers:

(18) Therefore, the findings of the cardiac cohort and nested case-control study of PCSF will be an important source of evidence and will provide an information base for long-term cardiac follow-up guidelines of CCS. (10_1371_journal_pone_0162778)

(19) Strictly speaking, the significance of addition of oxaliplatin to 5- fluorouracil plus folinic acid would also remain unclear for colorectal metastases in our opinion. (10_1371_journal_pone_0162400) 
Exploratory Study of Epistemic Stance in Results and Discussion Sections of Medical Research Articles

These two sentences reflect a higher level of certainty. On the one hand, example (18) expresses the confidence of the writer in assuring the readers about the findings of the study in terms of providing guidelines for CCS. Example (19), on the other hand, highlights the writer's opinion about the importance of the addition of particular acids and demonstrates a weaker commitment to the proposition. The writer of example (18) must have provided evidences for the assertion throughout the study and that is why the stance is strong and solid whereas the same does not seem to be the case in example (19).

The last modal verbs 'should' and 'must' were the least used epistemic modals. All instances of 'must' were found to be exclusively deontic obligation and were therefore also not included in the analyses. An example of the deontic usage of 'must' is given below and it can easily be understood from this sentence that here 'must' is used to express an obligation which is necessary for the study to have accurate results.

(20) That $[\mathrm{ACP}]$ does not become a formality, a consensus on paper with a hierarchical structure and a number of conditions which must be complied with. (Female GP, 40 years, FG 1) (10_1371_journal_pone_0084905)

Likewise, the epistemic modal 'should' was rare in the corpus. The primary function of this modal was the deduction based on a prejacent or co-text:

(21) Between 1999 and 2013, however, there was no major change in the dental care remuneration system [14], and the influence of the year of cancer diagnosis on the comparison between the short- and long-term follow-ups should be minimal. (10_1371_journal_pone_0182877)

In sentence (21), there is a deduction made on the grounds that there was no alteration in that specific medical field area, therefore, this must be valid for the comparison between short- and long-term follow-ups.

\section{B. Hedges}

Regarding the hedging function signaled by lexical items, it was found that because of the relatively small size of the corpus, the occurrences of lexical hedges were not high. Table 2 shows the most frequent hedges, excluding modal verbs which also function as a hedge but were treated separately, as explained in Section 3. The ratio of all the verbs presented in the table includes the occurrences of their inflected versions (such as 'suggest', 'suggests', 'suggested'). 'Likely (to)' was by far the most frequently employed hedging device (when modal auxiliaries are excluded) and was used both as an adjective with the meaning of 'probable' and as an adverb expressing the probability of the action. When the concordance plot was examined, 'likely' showed dominance and was generally used in the conclusion paragraphs in order to signal wrapping up the results and specifying the probability of a finding by making generalizations, suggesting an outcome or recommending further research.

Table 2. Frequency of lexical hedges 


\begin{tabular}{|c|c|c|c|}
\hline Lexical Hedges & $f$ & $\begin{array}{l}\text { per 10,000 } \\
\text { words }\end{array}$ & Examples from the corpus \\
\hline likely & 142 & 6.60 & $\begin{array}{l}\text { Integrated system would likely bias our findings } \\
\text { towards.. }\end{array}$ \\
\hline indicate & 119 & 5.53 & These factors both indicate a lower risk... \\
\hline estimate & 114 & 5.29 & We estimate that we will have 750 cardiac cases ... \\
\hline suggest & 110 & 5.11 & The results suggest hospital only palliative... \\
\hline possible & 102 & 4.74 & The other possible explanation is that... \\
\hline often & 83 & 3.85 & Delivering treatment often becomes unrealistic ... \\
\hline approximately & 67 & 3.11 & $\begin{array}{l}\text { OSCCs made up only approximately } 25 \% \text { of } \\
\text { cancers ... }\end{array}$ \\
\hline appear & 46 & 2.14 & Cancer stage and grade did not appear to affect ... \\
\hline seem & 42 & 1.95 & Chest wall tumours seem to be ... \\
\hline generally & 36 & 1.67 & Old patient age is generally a high risk ... \\
\hline
\end{tabular}

(22) It is likely a unique genetic background, as exemplified by the concurrence of $\mathrm{BC}$ and $\mathrm{TC}$ in certain tumor syndromes, such as the PTEN gene defect-associated Cowden Syndrome ... (10_1371_journal_pone_0221093)

In example (22), the writer(s) explain that the findings which were made led them to suggest probable causes for that specific alignment. The proposition is also supported by the exemplifications which emerged from the findings. However, the reason why the writer(s) weakened their claims could have been to protect themselves from making a false claim since their findings may not be enough to fully support their assertion. The writer(s) possibly chose to use a more tentative tone for that reason.

Overall, the hedges showed a tendency to spread across all the sections analysed because of the decision to explore only the results and discussion sections of articles. 'Indicate', 'estimate' and 'suggest' were the most used hedging verbs to present findings and set the discussion. It is not surprising that these verbs had high occurrence considering that the data is the sole resource on which the writers were basing their evaluations. They were generally followed by 'that ...' clauses. Around $49 \%$ of the instances of the verb 'indicate' and $76 \%$ of the epistemic verb 'suggest' were supported by adjacent 'that' clauses, whereas the verb 'estimate' did not show any particular pattern. The adjective 'possible' was the next most frequently used hedge and it was often used in close proximity to nouns such as 'explanation' and 'reason'. It is understandable that the reason for the high occurrence of the adjective 'possible' over the adverb 'probably' was the higher degree of uncertainty and this tendency demonstrates that in this specific field, authors are prone to be speculative about their claims. However, the frequency of the adverb 'often' shows a stronger commitment than the other hedges used. This could be because of a consensus on shared knowledge or the typicality of a particular case.

\section{Boosters}


Exploratory Study of Epistemic Stance in Results and Discussion Sections of Medical Research Articles

Table 3 shows the frequencies of the most frequent boosters in the data. As can be understood from Tables 2 and 3, hedges had more diverse instances than boosters, but some boosters had more occurrences than the most dominant hedges. The most commonly used booster was sthe verb 'show'. The frequency of the verb includes the past, present and third person singular inflections. The same is the prevailing case for other boosters listed in Table 3.

Table 3. Frequency of boosters

\begin{tabular}{lcc}
\hline Boosters & $\boldsymbol{f}$ & per 10,000 words \\
\hline show & 296 & 13.75 \\
find & 266 & 12.35 \\
demonstrate & 122 & 5.67 \\
know & 49 & 2.28 \\
establish & 40 & 1.86 \\
think & 25 & 1.16 \\
believe & 21 & 0.98
\end{tabular}

Every booster was analysed considering its respective instances. The epistemic verb 'show' was accompanied by 'that ...' clauses in approximately $46 \%$ instances of entire sample and the 'show-ed that the+noun' pattern was highly apparent in the corpus. The noun 'study' was the predominant word which was followed by this particular booster. The field-specific noun 'patient(s)' was the second preferred combination. The verb 'show' displayed a high degree of certainty on the part of the writer and strengthened the claim or proposition.

(23) Our study also showed a significant dose-response relationship in all patients. (10_1371_journal_pone_0198134)

Example (23) from the corpus represents the primary usage of the verb 'show'. The author presents a strong commitment to the findings and expresses confidence in them. This could be on account of the emphasis provided by the noun phrase 'all patients'. The verbs 'find' and 'demonstrate' were the second and third most used boosters and they showed similarity with the verb 'show' in terms of usage. Furthermore, 32\% instances of the verb 'demonstrate' were accompanied by 'that' clauses and the nouns 'results' and 'study' acted as the subject of the instances. Moreover, about $35 \%$ of the instances of 'find' were linked with 'that' clauses and $30 \%$ of its instances followed the subject pronoun 'we':

(24) In addition, we found no evidence that patients aged $<50$ years are particularly vulnerable to IBS development. (10_1371_journal_pone_0144589)

The use of 'we' implies the plurality of the researchers carrying out the studies and the verb 'found' in example (24) conveys the exact results of the study and this shows a significantly high commitment when 'we' is accompanied by a derivative of the strong verb 'find'. 
The relatively infrequent use of the verb 'know' could implicitly state a low level of certainty because this booster directly puts the author's belief at the centre. Similarly, the booster 'believe' might have lacked abundancy because it hints at an overall low level of certainty in the entire data.

\section{Overall findings}

The results of the exploration of resources signaling an epistemic stance showed that hedging was the most frequently used function in the data composed of the results and discussion sections of medical research articles. Figure 2 illustrates modal auxiliaries (excluding instances of 'must' and 'will' functioning as boosters) in the hedges category and epistemic modal auxiliaries constituted $45 \%$ of all hedge instances. This figure shows the dominance of hedges over boosters across the data. This indicates the authors' tendency to hedge assertive claims to ensure the reasonability rather than the accuracy of their propositions.

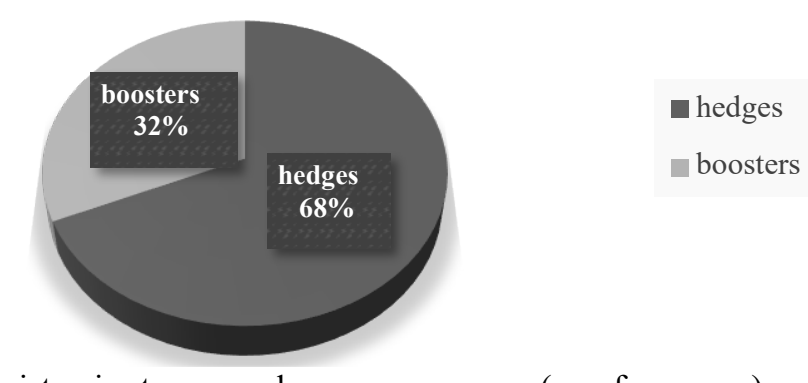

Figure 2. Epistemic stance markers across corpus (raw frequency)

Hyland and Jiang's (2016) analysis of stance indicated a similar outcome in terms of evidentiality to the findings of this current study and stated that in the discipline of biology, which is a relatively close field to medical sciences, the use of hedges was more frequent than boosters. Their findings correspond with the results of the present study. Likewise, Yang et al. (2015) identified the tentativeness employed by medical research writers and suggested that they avoid being subjective. The dominance of hedges in the present study conforms to those findings. The reason for the low instances of the boosting function of epistemic stance in the data could derive from the writers' need to avoid possible later accusations if the data is found not to be accurate or they lack confidence in the study. One particularly apparent point is that boosters were mostly used in conveying the results based on the findings. This signals that writers employ boosting and seek to strengthen their proposition when there is no need for personal judgement or evaluation. Likewise, since the nature of medical studies predominantly requires experimental research, the tendency to hedge quantities prevails in the interpretations. It is interesting that hedging adverbs such as 'probably', 'most likely' and 'possibly' were used less than modal auxiliaries. This indicates the importance of modals for conveying the epistemic stance of a writer. 
Exploratory Study of Epistemic Stance in Results and Discussion Sections of Medical Research Articles

To sum up, this study only analysed a relatively small corpus and only two sections of research articles, and further analysis of epistemic stance with broader data might provide more effective cohesion over the use of epistemic stance. Although hedging has been shown to be more common and safe for writers in this field and writers tend to try to avoid boosting based on the present findings, this might be different in other disciplines which can be accepted as soft, such as philosophy and sociology. It is plausible to claim that the nature of the medical field requires relatively more frequent use of hedging to construct knowledge and the importance of planning the teaching of academic writing to consider how writers convey their level of certainty to readers and persuade them.

\section{Practical Implications}

As has been shown by the samples provided throughout this paper, in academic writing, the writers express their epistemic stance in different ways. They interact with the readers by softening their participation or making it strong towards the propositions which they offer. For writers in specific fields, especially novice writers, this knowledge can be crucial and necessary for them to produce coherent and well-developed academic texts which signal their commitment to or detachment from an issue and persuade their readers (Akbaş, 2014; Akbaş \& Hardman, 2018). Reflecting their beliefs and ideas in the safest or most convincing way will potentially provide their readers with the opportunity to raise logical inferences based on the authorial stance on the evidentiality of claims or information presented in the text. Therefore, academic writing classes, mainly EAP, could be planned considering the field-specific usage of epistemic stance in articles. The writing activities undertaken in training should target particular markers and their contribution to epistemic stance.

Teachers should provide learners with the basics of epistemic stance and the importance of it to the text by exposing them to examples of the various epistemic usages and the meaning which they contribute to a text. Recognition of this can be regarded as the most crucial part of dealing with any type of learning. Learners should be introduced to the different functions of modals and be aware of the value of hedges and boosters as epistemic devices. Compiling an occurrence plot of such devices can be another useful step since students should know that introducing a new topic and sharing common knowledge do not necessarily require hedging or boosting.

To enable learners to understand the concept and significance of epistemic stance and to be able to use linguistic and semantic devices to convey it, teachers can implement several activities which are recommended below:

a) Putting given sentences in order to form a paragraph.

Example: 'Put these sentences in order from the most precise to the most hedged meaning and discuss which of the authors are detaching from their propositions less than others'. 
(1) Missing values can be a problem in propensity score analysis. (10_1371_journal_pone_0165705)

(2) Such PPVs will be adequate for many large-scale epidemiological studies of the determinants of stroke. (10_1371_journal_pone_0140533)

(3) Some scholars also suggested that postoperative radiotherapy might be an effective way in the treatment of ATC. (10_1371_journal_pone_0164840)

\section{b) Rewriting sentences}

Example: 'Rewrite the given sentences by weakening the claim which they present'.

(4) Timely identification and control of CVD risk factors will likely improve the overall survivorship of older women with localized breast cancer. (10_1371_journal_pone_0184174)

\section{c) Paragraph writing}

Example: 'Write a short paragraph using the following hedging and boosting devices: 'certainly, show, suggest, find, truly, evidently, definitely, indeed, approximately, tend to'. After you have completed your paper, give it to your partner and take his/hers. Check and edit your partner's paragraph if needed':

Activities such as these can help learners to have a better understanding of the concept of epistemic stance and expose them to the use of hedges and boosters. Teachers should guide learners while implementing the activities and give them critical feedback. They should point out and emphasize how these devices change the meaning and contribute to the need to be cautious when making assertions.

\section{Conclusion}

In this study, the use of epistemic stance in the results and discussion sections of medical research articles has been analysed focusing on the hedges, boosters and modal auxiliaries provided in Hyland's (2005a) list of interactional markers. Attitude markers presented in Hyland's framework were not included since the stance which they convey is not epistemic. This paper has presented a set of practical implication activities for academic writing classes, specifically for writers in the broad medical field. The importance of awareness of authorial presence and the ways of weakening or strengthening propositions have been emphasized throughout the paper.

As the results have shown, researchers in the field of medicine tend to hedge their claims rather than boost them. This tendency provides them with the cautiousness and tentativeness which they might need in terms of the field-specific nature of their studies (Yang et al., 2015). It is of capital importance especially for novice writers to write their papers bearing this in mind. However, to achieve this aspect of interacting with readers, writers should have an extensive knowledge of their field and their specific audience. In addition, writers should understand that hedging or boosting is not appropriate every time and that excessive usage of these devices might not provide them with the intended outcome. 
Exploratory Study of Epistemic Stance in Results and Discussion Sections of Medical Research Articles

In the process of the data analysis, only one framework was taken as a basis. However, there are studies which have considered multiple frameworks (for example, Poole et al., 2019). If there are any missing items in this study which are important for indicating epistemic stance, this is due to working with a deliberately limited list of epistemic markers. Another constraint which this study has is that the data set was relatively small so there were not many instances of markers. Further studies could work with larger data sets and various sources of epistemic markers targeting epistemic lexical bundles. As Hyland (2012:1) emphasized, lexical bundles are "key components of fluent linguistic production, marking out novice and expert use in a range of genres". Through such studies, learners can explore the most frequent formulaic patterns and make use of those patterns to convey their epistemic stance to the knowledge or propositions which they present.

\section{References}

Akbaş, E. (2014). Commitment-detachment and authorial presence in postgraduate academic writing: A comparative study of Turkish native speakers, Turkish speakers of English and English native speakers [Doctoral dissertation, University of York]. http://etheses.whiterose.ac.uk/7083

Akbaş, E., \& Hardman, J. (2018). Strengthening or weakening claims in academic knowledge construction: A comparative study of hedges and boosters in postgraduate academic writing. Educational Sciences: Theory and Practice, 18(4), 831-859. https://doi.org/10.12738/estp.2018.4.0260

Anthony, L. (2019). AntCorGen (Version 1.1.2) [Computer Software]. Tokyo, Japan: Waseda University. https://www.laurenceanthony.net/software

Anthony, L. (2020). AntConc (Version 3.5.9) [Computer Software]. Tokyo, Japan: Waseda University. https://www.laurenceanthony.net/software

Biber, D. (2006). Stance in spoken and written university registers. Journal of English for Academic Purposes, 5(2), 97-116. https://doi.org/10.1016/j.jeap.2006.05.001

Biber, D., \& Finegan, E. (1988). Adverbial stance types in English. Discourse Processes 11, 1-34. https://doi.org/10.1080/01638538809544689

Biber, D., \& Finegan, E. (1989). Styles of stance in English: Lexical and grammatical marking of evidentiality and affect. Text, 9, 93-124. https://doi.org/10.1515/text.1.1989.9.1.93

Biber, D., Johansson, S., Leech, G., Conrad, S., \& Finegan, E. (1999). Longman Grammar of Spoken and Written English. Pearson Education.

Brown, P., \& Levinson, S. (1987). Politeness: Some Universals in Language Use. Cambridge University Press. https://doi.org/10.1017/CBO9780511813085 
Chafe, W., \& Nichols, J. (Eds.). (1986). Evidentiality: The linguistic coding of epistemology. Ablex.

Çiftçi, H., \& Akbaş, E. (2021). Stancetaking in spoken ELF discourse in academic settings: interpersonal functions of I don't know as a face-maintaining strategy. Eurasian Journal of Applied Linguistics, 7(1), 484-502. https://doi.org/10.32601/ejal.911499

Gray, B., \& Biber, D. (2014). Stance markers. In K. Aijmer \& C. Rühlemann (Eds.), Corpus Pragmatics: A Handbook (pp. 219-248). Cambridge University Press. https://doi.org/10.1017/CBO9781139057493.012

Halliday, M. A. K. (2004). The language of science. In J. Webster (Ed.), Collected works of M. A. K. Halliday. Continuum.

Hunston, S., \& Thompson, G. (2000). Evaluation in text: authorial stance and the construction of discourse. Oxford University Press.

Hyland, K. (1998). Boosting, hedging and the negotiation of academic knowledge. Text \& Talk, 18(3), 349-382. https://doi.org/10.1515/text.1.1998.18.3.349

Hyland, K. (2005a). Metadiscourse: Exploring Interaction in Writing. Continuum.

Hyland, K. (2005b). Stance and engagement: A model of interaction in academic

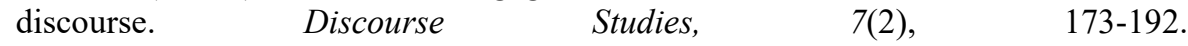
https://doi.org/10.1177/1461445605050365

Hyland, K. (2012). Bundles in academic discourse. Annual Review of Applied Linguistics, 32, 150-169. https://doi.org/10.1017/S0267190512000037

Hyland, K., \& Jiang, F. (2016). Change of attitude? A diachronic study of stance. Written Communication, 33(3), 251-274. https://doi.org/10.1177/0741088316650399

Ochs, E., \& Schieffelin, B. (1989). Language has a heart. Text, 9, 7-25. https://doi.org/10.1515/text.1.1989.9.1.7

Poole, R., Gnann, A., \& Hahn-Powell, G. (2019). Epistemic stance and the construction of knowledge in science writing: A diachronic corpus study. Journal of English for Academic Purposes, 42, 100784. https://doi.org/10.1016/j.jeap.2019.100784

Varttala, T. (2001). Hedging in scientifically oriented discourse. Exploring variation according to discipline and intended audience [Doctoral dissertation, University of Tampere]. https://trepo.tuni.fi/handle/10024/67148

Vassileva, I. (2001). Commitment and detachment in English and Bulgarian academic writing. English for specific purposes, 20(1), 83-102. https://doi.org/10.1016/S08894906(99)00029-0

Vázquez, I. (2010). A contrastive analysis of the use of modal verbs in the expression of epistemic stance in Business Management research articles in English and Spanish. Ibérica, 19, 77-95. 
Exploratory Study of Epistemic Stance in Results and Discussion Sections of Medical Research Articles

White, P. R. R. (2003). Beyond modality and hedging: A dialogic view of the language of intersubjective stance. Text, 23, 259-284. https://doi.org/10.1515/text.2003.011

Yang, A., Zheng, S., \& Ge, G. (2015). Epistemic modality in English-medium medical research articles: A systemic functional perspective. English for Specific Purposes, 38, 1-10. https://doi.org/10.1016/j.esp.2014.10.00 